\title{
DIE UITVERKIESINGSLEER EN DIE SENDINGSVERKONDIGING
}

\author{
Deur Ds. P. A. Geyser*
}

\section{Inleiding}

Hoe raak die begrip van wie gered is en wie verlore is die sendingaksie van die kerk? Daar word soms gestel dat die "sendinglouheid" van die kerke van die reformasie in die sestiende eeu toe te skryf is aan hulle uitverkiesingsleer. Die probleem van die sogenaamde sestiende eeuse sendinglouheid of daar selfs sprake van so iets kan wees en watter faktore almal 'n rol gespeel het by die beīnvloeding van die reformatore se visie van die sending en die sendingpogings van daardie tyd kan nie in hierdie studie aandag geniet nie.

Wel sal ons kortliks aandag moet gee aan wat die sendingmotief van die kerk is of moet wees. Insonderheid kom die sendingmotief van die piëtisme binne die gesigsveld in die lig van die hierbo gestelde vraag. Want die grondmotief by die piëtiste was veral die medelye. Medelye wat nie net gewek is deur deernis met die heiden in sy liggaamlike nood nie, maar ook en veral medelye met hom omdat hy in gevaar verkeer om vir ewig verlore te gaan. Uit medelye met sulke mense wat geen ander toekoms het nie as om ewig verlore te gaan word die evangelie dan verkondig om siele vir Gods Koninkryk te wen.

Algemene opvatting was dat alle mense en volke wat Christus nie ken nie - nog nooit van Hom gehoor het nie verlore sal gaan.

Veral egter sal dit moet gaan om begrip van die uitverkiesing. Daarom sal die klassieke predestinasieleer van die reformasie en ook latere visies die aandag moet geniet. Aangesien hierdie ' $n$ onderwerp is met 'n ontsaglike omvang - veral wat literatuur oor hierdie saak betref - sal daar noodwendig 'n seleksie gemaak moet word.

Daarom kan hierdie studie hoogstens 'n sketsmatige poging verteenwoordig om self tot ' $n$ beter begrip van hierdie saak te kom - al is dit dan ook net tot 'n beter begrip van die gehoorsaamheid waarin die kerk sy taak moet uitvoer en tot die begrip van diepte van die rykdom en wysheid en kennis van God. 


\section{Die Uitverkiesingsleer by Calvyn}

Vir die tradisioneel-ortodokse siening van die uitverkiesing het ons vir die doeleindes van hierdie studie uitgegaan van die standpunt van Johannes Calvyn, de man wat grootliks verantwoordelik was vir die vergestalting van die reformatoriese gedagte.

Calvyn se uitgangspunt by sy leer oor die uitverkiesing is: dat ons nooit genoegsaam oortuig sal wees dat ons saligheid voortvloei uit die vrye genade van God as bron daarvan, voordat ons nie kennis geneem het van Sy ewige verkiesing nie, aangesien die genade van God juis geillustreer word deur die kontras : dat God nie sonder onderskeid aanneem tot die hoop van die saligheid nie, maar dat $\mathrm{Hy}$ aan sommiges gee wat $\mathrm{Hy}$ aan ander ontsê. En nou is dit duidelik hoe onkunde aangaande hierdie beginsel afbreuk doen aan die eer van God en die ware nederigheid verswak. ${ }^{1}$

Maar die ondersoek na die uitverkiesingsleer gaan gepaard met die waarskuwing: dat hulle wat navraag doen na die predestinasie dít in gedagte moet hou dat hulle binnedring in die skuilhoeke van die goddelike wysheid en daarom sal hy wat met oorvertroue en sekerheid instorm in onontrafelbare dwaalgange beland in plaas daarvan om sy nuuskierigheid te bevredig. ${ }^{2}$

En daarom stel hy dit as eerste beginsel : om enige kennis van die predestinasie te begeer buiten wat die Woord stel is nie minder gek as om te loop waar daar geen paadjie is of om lig te soek in die duisternis nie. ${ }^{3}$

Die aard van hierdie studie laat nie ruimte vir meer oor Calvyn se uitgangspunt nie. En ook vir die verdere ontvouing van die saak sal daar 'n seleksie gemaak moet word om die stof wat ter sake is vir die sending na vore te bring. Noodwendig sal die geheelbeeld van Calvyn se uitverkiesingsleer daaronder ly, omdat hier slegs grepe uit die geheel, met die oog op die sending, uitgelig sal word.

Vir Calvyn val die hele struktuur van die uitverkiesingsleer baie strak en skerp omlyn: Met predestinasie bedoel ons die

* Verhandeling ingedien ter vervulling van 'n deel van die vereistes vir die B.D. graad aan die Universiteit Pretoria, onder leiding van prof. F. J. van Zyl, November 1967.

1. Calvin, Institutes of the Christian Religion, translated by $\mathrm{H}$. Beveridge (Eerdmans Publishing Co., Michigan, 1962).

2. Inst. III: XXI, 1 .

3. Inst. III: XXI, 1 . 
ewige dekreet/verordening van God waardeur Hy by Homself bepaal het wat $\mathrm{Hy}$ wou laat gebeur met elke mens. Almal is nie op gelyke voet geskape nie, maar sommiges is vantevore verordineer (praeordinatur) tot die ewige lewe en ander tot die ewige verdoeming; en in ooreenstemming hiermee — dat almal vir een van hierdie twee bestemmings geskape is - praat ons daarvan dat hy gepredestineer is tot die lewe of tot die dood."

N.a.v. die geslag van Abraham wat verkies is (Gen. $12: 2$ ) waarvan sommige toe tog verwerp is (Ismael) stel Calvyn dat God in Sy verkiesing van die hele nasie reeds getoon het dat $\mathrm{Hy}$ in die uitoefening van Sy suiwere vryheid onder geen wet gestaan het nie, maar dat Hy vry was en daarom op generlei wyse beperk of gebind aan 'n gelyke verdeling van genade nie - dat juis die ongelykheid daarvan dit bewys dat dit genade is."

Die Skrif bewys duidelik dat God in Sy ewige en onveranderlike raad dit eens en vir altyd vasgestel het wie almal dit Sy welbehae is om eendag tot die saligheid toe te laat, en ook hulle aan die anderkant wat in Sy welbehae verdoem is tot vernietiging. Calvyn handhaaf dat hierdie raadsbesluit wat die uitverkorenes betref, berus op Gods vrye genade sonder enige aansien van menslike waardigheid. Terwyl hulle wat Hy verdoem tot die vernietiging uitgesluit/weerhou is van die toegang tot die lewe deur 'n regverdige en onberispelike, maar terselfdertyd, onverstaanbare oordeel. Wat die uitverkorenes betref beskou hy die roeping as getuienis/bewys van hul verkiesing, en die regverdiging as 'n verdere teken daarvan totdat dit (die verkiesing) ten volle gerealiseer word in die verkryging van die heerlikheid (verheerliking).

Maar soos die Here Sy verkorenes verseël deur die roeping en regverdiging so verberg $\mathrm{Hy}$ in 'n sekere sin die oordeel wat op die verworpenes wag deurdat $\mathrm{Hy}$ hulle óf weerhou van die kennis van Sy naam of van die heiliging deur die Heilige Gees. ${ }^{6}$

Wanneer dit gaan oor die oorsprong en oorsaak van die uitverkiesing soek Calvyn die antwoord in die geheime raadsbesluit van God. Hy stel dit klaarblyklik teenoor diegene wat die voorkennis van God t.o.v. die uitverkiesing so verdedig dat die uitverkiesing sou berus op Gods voorkennis aangaande die deugde of ondeugde van die mense. Daarteenoor stel Calvyn dat die enigste saak wat werklik oorweging vra is wat God behaag het en nie wat mense uit hulself voorsien nie. Want in

4. Inst. III: XXI, 5 .

5. Inst. III: XXI, 6 .

6. Inst. III: XXI, 7 . 
laaste instansie is dit seker: alle oorsake wat mense wil ontwerp (vir die uitverkiesing) buite om die geheime raadsbesluit van God, word uitgesluit deur die gebruik van die terme „voorneme" en ,verkiesing."

Die saligheid van die gelowiges berus geheel en al op die verordening van goddelike verkiesing en hierdie voorreg word verkry nie deur die werke nie, maar deur die vrye roeping (genade).

En daarom, as ons geen ander rede kan aantoon waarom Hy aan Sy volk genade bewys behalwe dat dit Hom so behaag nie, sal ons ook geen ander rede kan aantoon waarom $\mathrm{Hy}$ die ander verwerp, as Sy wil nie. As van God gesê word dat Hy sommiges begenadig en ander verhard moet ons geen ander oorsaak soek bo en behalwe Sy wil nie. ${ }^{8}$

In der waarheid praat Calvyn ook oor Jesus Christus i.v.m. die uitverkiesing :

In die eerste plek, as ons soek vir die vaderlike genade en guns van God moet ons die oë rig op Christus, want slegs in Hom het die Vader 'n welbehae (Mt. 3:7). Daarom word van hulle wat God aangeneem het as kinders, gesê dat Hy hulle uitverkies het in Christus (Ef. 1:4) omdat Hy (God) hulle slegs kon liefhê in Hom (Christus) en slegs insoverre hulle vantevore deel gekry het aan Christus, vereer God hulle met die erfdeel van Sy koninkryk. Daarom, as ons in Hom uitverkies is kan ons nie die sekerheid van ons verkiesing in onsself vind nie, selfs nie eers in God die Vader as ons na Hom kyk los van die Seun nie. Christus dan is die spieël waarin ons ons verkiesing behoort en in werklikheid sonder bedrog kan bedink.

As ons dus in gemeenskap met Christus is het ons genoegsame duidelike en sterk bewys dat ons opgeteken is in die boek van die lewe. ${ }^{9}$

Maar tog kan mens die indruk nie ontkom dat Jesus Christus vir Calvyn nie die grond van die uitverkiesing is nie, maar slegs die middel waardeur God Sy ewige en geheime raadsbesluit tot uitvoering laat kom:

Calvyn haal met instemming vir Augustinus aan waar lg. stel dat ons in die Hoof van die Kerk 'n helder spieël het van die vrye verkiesing sodat dit geen probleem hoef te wees vir die

7. Inst. III: XXII, 4.

8. Inst. III: XXII, 11 vgl. ook XXIII, 1,7 ens.

9. Inst. III: XXIV, 5 . 
lede nie - dit is : Hy het nie die Seun van God geword deur opreg/regverdig te lewe nie, maar hierdie groot eer is Hom vrylik aangebied sodat Hy ook daarna aan ander deel kon gee aan Sy gawes. ${ }^{10}$

Daarom interpreteer hy ook die woorde van Paulus in Ef. 1:4: „Soos Hy ons in Hom uitverkies het voor die grondlegging van die wêreld om heilig en sonder gebrek voor Hom te wees in liefde...", dat Paulus hier stel dat ons eie waarde hoegenaamd nie in ag geneem word nie. Ons word dus in Christus tot hierdie hemelse erfenis aangeneem omdat ons in onsself nie in staat was om so 'n heerlikheid te bekom nie.

Dit is ook eintlik vir Calvyn die antwoord op die vraag wat hy self stel: As die verkiesing voorafgaan aan die goddelike genade waardeur ons geskik gemaak word om die ewige lewe te ontvang, wat sou God kon beweeg om ons te verkies? Omdat daar geen deugde in die mens self is nie, daarom word hulle in Christus verkies - die versoeningswerk van Christus is dus bemiddelend. As daar dan 'n hoër oorsaak gevra word vir hierdie verkiesing stel Calvyn dat Paulus antwoord: die predestinasie van God en Hy het so gepredestineer ooreenkomstig die welbehae van Sy wil.11

Wat die prediking van die Woord betref stel Calvyn t.o.v. die verkorenes dat dit wel moontlik is om op te roep tot 'n vroom lewe : laat die prediking sy vrye loop hê sodat dit mense tot die geloof kan bring en hulle van so 'n gesteldheid maak dat hulle sal volhard met ononderbroke vooruitgang. Maar laat daar terselfdertyd geen hindernis wees ten aansien van die kennis van die uitverkiesing nie, sodat die wat gehoorsaam, nie op hulself sal roem nie maar die Here sal verheerlik. ${ }^{12}$

Maar soos die Here deur die werksaamheid van Sy roeping die (saligheid) verlossing volvoer aan Sy verkorenes, die verlossing naamlik waartoe Hy hulle in Sy ewige raadbestem het, net so het Hy oordele teenoor die verworpenes waardeur $\mathrm{Hy}$ Sy raadsbesluite waarvoor hulle bestem is ook uitvoer. Hulle naamlik wat Hy geskep het tot skande/oneer tydens hulle lewe en vernietiging by die dood, om hulle voorwerpe van Sy toorn en voorbeelde van gestrengheid te maak, van hulle weerhou $\mathrm{Hy}$ by tye die moontlikheid om Sy Woord te hoor en by tye gebruik Hy juis die prediking om hulle te verblind en te verwar.

10. Inst. III: XXII, 1 .

11. Inst. III: XXII, 1, 2 vgl. ook 9 .

12. Inst. III: XXIII, 13. 
Hiervan sien Calvyn 'n voorbeeld in die gebeure voor die koms van Jesus Christus : waartydens vir plus-minus 4,000 jaar die lig van $\mathrm{Sy}$ verlossingsleer vir al die ander nasies versteek was. ${ }^{13}$

Die weiering van die verworpenes om die Woord van God te gehoorsaam wanneer dié aan hulle geopenbaar word kan heel goed toegeskryf word aan die kwaadwilligheid en ontaarding van hulle harte; mits daar hierby gevoeg word dat hulle veroordeel is tot hierdie onntaarding omdat hulle juis opgevoed is deur die regverdige dog onnaspeurlike oordeel van God om Sy heerlikheid te openbaar deur hulle verdoeming. ${ }^{14}$

Calvyn wil dus ten aansien van die prediking onderskei tussen twee "spesies" van roeping: daar is die universele roeping waardeur God, deur die uitwendige prediking van die Woord, alle mense uitnooi, selfs ook hulle vir wie Hy hierdie roeping ontwerp as 'n geur van die dood en die grond vir strenger verdoeming. Daarnaas is daar 'n besondere roeping wat God vir die grootste deel slegs aan die gelowiges verleen wanneer $\mathrm{Hy}$ deur die interne verligting van die Gees die Woord wat gepredik is diep in hulle harte laat wortel skiet. ${ }^{15}$

Calvyn wil dus niks anders leer as wat die werklikheid ook maar bewys nie nl. dat God nog altyd die vryheid gehad het om Sy genade te betoon aan wie Hy wil. ${ }^{16}$

Die beloftes van die verlossing geld dus besonderlik die uitverkorenes. En die leer van die verlossing word geskenk as dit voorgestel word asof dit effektief beskikbaar is vir almal.

Daarom wil hy volstaan deur op te merk dat hoewel die woord van die Evangelie aan almal in die algemeen gerig is, die gawe van die geloof tog seldsaam is. ${ }^{17}$

Maar nogtans, hoe universeel die beloftes van die verlossing ookal mag wees, daar is geen teenstrydigheid tussen die beloftes en die predestinasie van die verworpenes nie. Dit is : tussen die feit dat God die getal vasgestel het van hulle waarin Hy 'n welbehae het om hulle in liefde aan te neem en hulle oor wie Hy 'n welbehae het om Sy toorn aan hulle te openbaar, en dat $\mathrm{Hy}$ die verlossing aanbied sonder onderskeid nie. 13. Inst. III: XXIV, 12 Vgl. ook gesk. van Moses by Farao. Vgl. Jes.
$6: 9,10$.

14. Inst. III: XXIV, 14.

15. Inst. III: XXIV, 8.

16. Inst. III. XXII, 1 .

17. Inst. III: XXII, 10. 
Calvyn sien die houdbaarheid van die twee sake daarin : al wat bedoel word met die belofte is dat Sy genade aangebied word aan almal wat dit begeer en soek - en dit doen niemand behalwe diegene wat Hy verlig het nie. Bowendien, Hy verlig slegs hulle wat $\mathrm{Hy}$ gepredestineer het tot die verlossing. ${ }^{18}$

Tot sover dan Calvyn. N.a.v. sy uitverkiesingsleer kan verstaan word waarom dit ook o.a. aangedien word as verskoning vir die reformatoriese „Missionslauheit."

Teenoor die uitverkiesingsleer van Calvyn wil ons enkele trekke van die uitverkiesingsleer van Karl Barth in oënskou neem omdat hy in bepaalde aspekte verskil van die ortodokstradisionele siening en ook kritiek het teen die visie van Calvyn oor herdie bepaalde saak.

\section{Karl Barth}

Ook van Barth kan daar maar enkele grepe van sy gedagtes oor die uitverkiesing weergegee word. Die aandag word eintlik toegespits op sy punte van kritiek op die tradisionele beeld en die gedagtes wat hy in die plek daarvan wil stel - ook en veral met die oog op die konsekwensies wat dit vir die sending het.

Die grondliggende betekenis van die uitverkiesingsleer sien Barth daarin dat dit genade is om genade te ontvang en genade beteken: die vaderlike weldaad van God om ons in die tyd en vir die ewigheid as Sy kinders aan te neem en te behandel m.a.w. die inhoud van die Woord. Die Woord van God se verkiesing het niks om toe te voeg tot die Woord van Gods genade nie. Dit onderstreep dit slegs op 'n baie merkwaardige en weliswaar onontbeerlike wyse. ${ }^{20}$

Daarom word ook geen selfstandige plek aan 'n uitverkiesingsleer gegee nie, maar dien dit as sout in die spys.

Die grondgedagtes van Barth oor die uitverkiesing kan ons kortliks probeer saamvat:

Die mens is nie van so 'n gesteldheid om die genade wat aangebied word te ontvang nie — ,wird die Gnade nie allezeit

18. Inst. III: XXIV, 17.

19. Vgl. H. W. Gensichen: Miss'onsgeschichte der neueren zeit/ (IV Band van ..D 2 Kirche in ihrer Geschichte" - uitgegee deur Schmidt und Wolff) bl. 15, hoewel Gensichen die gesigshoek bevraagteken waaruit die sendingspoging van die $16 \mathrm{de}$ eeuse Kerke van die reformasie beoordeel word as sou dit ."lou" gewees het.

20. K. Barth. Gottes Gnadenwahl, Heft. $47 / \mathrm{i} / \mathrm{d}$ reeks .,Theologische Fxistenz heute". uitgegec deur Ed. Thurneysen, Chr. Kaiser Verlag, München 1936, bl. 6 . 
Ungnade in unseren Händen indem wir sie verschmähen als ob wir sie nicht nötig hätten oder indem wir sie missbrauchen als ob wir Macht über sie hätten?"'21

Nou wil die uitverkiesing die weg beskryf waar en hoe die beslissing geneem word dat dit tot die stap kom dat wat aangebied word ook ontvang word, van die Woord tot die geloof, van die genade tot 'n lewe in die genade.

Maar nou is geen mens van so 'n aard dat hy uit homself die genade sal aanneem nie, en daarom is dit in der daad op sigself genade om genade te kan ontvang.

Dat die uitverkiesing die genade in die genade beteken wil ook Gods heerskappy en vryheid uitdruk. Daarom is dit dan ook voor-bestemming, prae-destinasie, omdat dit Gods handeling, Sy werk, Sy wil en Sy ryk is; en daarom berus die menslike beslissing geheel en al op die voor-beslissing van God - en hierdie voor-beslissing beteken: uitsondering, uitmerk, uitkies uit die mense. In hierdie vryheid van God is die voltrekking van die genade gegrond en daarin het die genade objektief gesag en subjektief sekerheid. ${ }^{22}$

Wanneer Barth stel dat die uitverkiesing openbaringswaarheid is - geloofsbelydenis, dan wil hy daarmee ook 'n dubbele negatief stel : uitverkiesing is geen denknoodwendigheid nie en ook nie voorwerp van ervaring nie. Alles wat vanuit hierdie twee negatiewe bronne die uitverkiesingsleer beïnvloed het was pogings om sekere onverklaarbaarhede menslikerwys meer verstaanbaar te maak, maar die prys was in der waarheid 'n vertroebeling van die werklike helderheid.

Die twee negatiewe bepalings vereis egter toeligting: Die genade-verkiesing is geen denknoodwendigheid: al word die oorgelewerde begrip prae-destinatio verstaan as die goddelike voor-bestemming of voor-beslissing moet duidelik verstaan word dat met hierdie „voor" daar op God heengewys word en daarmee dan nóg op 'n tydelike nóg op 'n logiese „voor" (prius). Die predestinasieleer is dus gewis nie die religieus verklaarde vorm van determinisme wat spesiaal aan die hand van religieuse ervaring afgelei is nie. Die uitverkiesing loën beide die determinisme en die indeterminisme (begrippe "noodwendigheid" en "wêreldbeginsel" hier geheel onvanpas, net soos "vryheid" aan die ander kant).

Barth meen dan ook dat die uitverkiesingsleer van Calvyn medebepaal is deur deterministiese beginsels. ${ }^{23}$

21. Barth, a.w., bl. 7.

22. Barth, a.w., bls. 8-10.

23. Barth, a.w., bl. 11 . 
Die genade-verkiesing is ook nie die voorwerp van ervaring nie : Ook hier was dit Calvyn wat graag die ervaring (experientia) aangedien het as bron van sy uitverkiesingsleer. Barth wys die ervaring as uitgangspunt vir 'n uitverkiesingsleer af, selfs al is die onderskeid nog so opvallend in die ervaring en die maatstaf waarmee gemeet word hoe bruikbaar. ${ }^{24}$

Gods verkiesing in genade is openbaringswaarheid - meer konkreet : dit is Skrifwaarheid - dit is waarheid in Jesus Christus. Belydenis van die uitverkiesing is in werklikheid ook niks anders as 'n bepaalde vorm van belydenis van Jesus Christus nie. Ii Jesus Christus uitverkies beteken dat wat ons van die uitverkiesing kan ken en daarmee van die verwerping ook, ons slegs kan ken in Jesus Christus en nie in 'n logies opgestelde denkbeeld of in die beeld van ons ervaring nie. ${ }^{2.5}$

In Jesus Christus uitverkies beteken in die eerste plek nie in onsself uitverkies nie. Die grond en bron vir die genade lê buite ons - dis nie in ons eie naam wat ons die waarheid en die heil ontvang nie. En bowendien : dis nie onder ons naam, maar weer eens onder Sy naam beslis dat ons die waarheid en die heil ontvang. In Hom as ons Hoof, in Hom as die ewige Seun van God, in Hom as die Middelaar tussen God en die mense. Voor hierdie ,in Hom" moet èn die rasionele èn die empiriese fundering van die predestinasie verstom!

Vir hierdie Christologiese fundering en uitgangspunt maak Barth ook ten volle erns met die vleeswording en opstanding van Jesus Christus. ${ }^{26}$

„In der Geburt Jesu Christi sind alle, die an ihn glauben, wiedergeboren zu kindern Gottes aus Gnade." "2;

„Was auf Golgotha für uns an uns geschehen und am Ostertag offenbar geworden ist, das ist - obwohl es in der Zeit geschehen ist - unsere ewige Erwählung."”s

In die lig hiervan stel Barth die baie beslissende vraag aan die klassieke begrip van die uitverkiesing: Watter raadsbesluit van God kan voor daardie werklikheid lê (die werklikheid van vleeswording, kruis en opstanding) as dit God self is wat in daardie werklikheid teenwoordig was en gehandel het, as die grond (van die verkiesing) self die middel was, as die uitverkiesende God self mens geword het?

24. Barth, a.w., bl. 12.

25. Barth, a.w., bl. 13.

26. Barth, a.w., bl. 14 .

27. Barth, a.w., bl. 15.

28. Barth, a.w., bl. 17. 
As ons die opstanding van Jesus Christus laat geld as die openbaring van ons versoening en antwoord ons ja teenoor hierdie versoening, sê ons daarmee ook ja teenoor die raadsbesluit van God.?

M.a.w. daar is geen hoër en oorspronkliker raadsbesluit van God as diè wat in Sy versoeningsdaad geopenbaar word nie. En die uitverkiesing is dan nie 'n ewige raadsbesluit vòò die werklikheid van kruis en opstanding nie. Hierdie versoening is Gods raadsbesluit.

Maar nou kry mens geen uitverkiesing waar daar nie ook nie-verkiesing, verbygaan, verwerping is nie. Daarom moet die leer van die predestinasie altyd leer van 'n dubbele predestinasie wees. Tog waarsku Barth baie sterk teen enige gedagte van gelyke gewig tussen verkiesing en verwerping, teen 'n simmetriese sistematisering asof mens op dieselfde wyse en met gelyke betekenis kan praat van 'n goddelike verwerping soos van die goddelike verkiesing. Met die oog op Golgota praat mens geheel anders oor die verwerping as wanneer mens vanuit die rede of die ervaring praat. Met die oog op Golgotha is daar van die gelyke gewig en simmetrie van verkiesing en verwerping geen sprake nie. ${ }^{30}$

Ons kan egter ons verkiesing in Jesus Christus nie erken/ bely sonder om eers en voor alles ook in Hom ons verwerping te erken nie. Want hier is dit die toorn van God wat van die hemel af geopenbaar word - hier word dit werklik geopenbaar aangesien die toorn hier die Een, uitverkore God, die een werklike Skuldlose en Gehoorsame tref.

Maar daarin dat Gods reg hier beslis en uitgevoer word, daarin dat ons verwerping hier openbaar word en weliswaar in sy geregtigheid geopenbaar word, daarin dat die uitverkore God dit hier bevestig in die geloof en op Homself neem, word dit as ons verwerping opgehef.

Hier sien ons, is dit met enige sprake van gelyke gewig van verkiesing en verwerping grondig verby. Wanneer ons kennis/ erkenning van ons verwerping ook in Jesus Christus soek, is dit hier juis die grootste ongelykheid tussen verkiesing en verwerping soos tussen bo en onder, gister en vandag, God en mens. Hier is geen simmetriese argitektuur nie, hier word 'n weg gegaan. En die predestinasieleer kan maar slegs die beskrywing van hierdie weg wees.

29. Barth, a.w., bl. 17.

30. Barth, a.w., bls.18-20. 
Ook hier is daar dus kritiek op die klassieke predestinasieleer waar die uitverkiesing gesien is as 'n ewige, onherroeplike raadsbesluit van God en waarin hierdie onveranderlikheid van God so verstaan is dat dit ' $n$ onbeweeglike toestand van die mense daargestel het in die onderskeiding en indeling van alle mense in verkorenes en verworpenes, gelowiges en ongelowiges, deelhebbers aan die ewige saligheid en deelhebbers aan die ewige verdoemenis.

„Die klassische Prädestinationslehre bedeutete in diesem Punkt eine unerlaubte Anthropologisierung, Mechanisierung und Stabilisierung des majestätischen göttlichen Entwederoder, unter das wir in Jesus Christus gestellt sind und dessen Bezeugung der Sinn der Biblischen Prädestinationslehre ist." ${ }^{31}$

Vir Barth gaan dit om die predestinerende God en nie om twee klasse van gepredestineerde mense nie. Ons is nie bevoeg om vas te stel wie uitverkies is en wie verwerp is nie. Selfs nie eers die algemene vasstelling dat daar verkorenes en verworpenes is as twee bepaalde klasse van mense, kan ons maalk nie.

Dat daar op die jongste dag van die gerig die een aangewys sal word as van ewigheid deur God verkies en die ander as van ewigheid deur dieselfde wil van God verwerp, gee hoegenaamd nie aan ons die reg om hier en nou met so ' $n$ indeling van die mensheid in verkorenes en verworpenes te werk nie - ons sou daarmee aan die genade en aan die heerskappy van Christus ongeoorloofde grense trek.

Wat ons hier en nou "het" is beide die gestaltes van die goddelike handeling en verkiesing: Gods uitverkiesing uit genade tot genade as die belofte waaronder ons lewe staan en Gods verwerping as ongenade tot ongenade, as die bedreiging (waarvan ons bevry word deur die belofte). ${ }^{32}$

Die insig waarvoor kennis van die genadeverkiesing ons in aanspraak neem is $\mathrm{nl}$. die dubbele insig van die geloof in Jesus Christus. In die geloof in Jesus Christus het Paulus dit geskryf en sal ons dit moet erken: „Want God het hulle almal in die ongehoorsaamheid ingesluit" - dit is die bedreiging, weliswaar die bedreiging waarvan ons bevry word deur die belofte in Jesus Christus aan ons gegee. Maar die belofte sluit dit in en bring ook tot uitdrukking: slegs deur hierdie belofte word ons van die bedreiging bevry. Buite om die belofte bestaan en geld die

31. Barth, a.w., bl. 24.

32. Barth, a.w., bl. 26 . 
bedreiging met die volle oordeel Gods - almal in die ongehoorsaamheid ingesluit.

In die geloof in Jesus Christus kan mens jou aan die insig nie onttrek dat ons verwerping beslis, verdiend en werklik voltrek is nie.

„Om vir almal barmhartig te kan wees" - dit is die belofte. Maar dit los die dreigement nie op nie. Dit is wel sy vooronderstelling dat ons verwerping beslis, verdien en voltrek is. Daarom was en is die dreigement geen spel nie. Die gehele erns daarvan word daarin sigbaar dat dit God niks minder as Sy eie Seun gekos het om ons daarvan te bevry nie.

„Dass Gott - Gott in Jesus Christus - durch solche Drohung und Verheissung in dieser doppelten und doch so ungleichen Vorherbestimmung dass uns auf dem Wege ist, uns in seiner Hand hălt, das ist die Einsicht, für die uns die Erkenntnis der Gnadenwahl in Anspruch nimmt. ${ }^{33}$

Maar hierdie insig sou ydele teorie bly as dit nie gedra en vervul word deur die vertroue nie. Die vertroue dat hierdie goddelike voorbestemming van ons lewens werklik goddelik is en dat ons so die ware doel vir ons daarin bereik. Ons is uitverkies wanneer/daarin dat ons ja sê teenoor ons uitverkiesing in Jesus Christus (daarmee sê ons ook ja teenoor ons verwerping wat deur Jesus Christus gedra en opgehef is en daarom tog voor alles en in die eerste plek ,,ja" teenoor ons verkiesing).

Maar hierdie vertroue word eers feitelik en prakties durend die gestalte van vrye menslike beslissing wanneer hierdie beslissing die karakter van gehoorsaamheid vertoon. ${ }^{34}$

Uitverkiesing in Jesus Christus beteken heiliging vir God, en dit beteken: dit stel ons met die troos van die evangelie onder die tug van Sy gebod; met die kindskap Gods van die versoening in die knegskap Gods van die boetedoening, met die vergewing van sonde by die aanvang van 'n nuwe lewe van gehoorsaamheid in die geloof.

Nadat die uitverkiesingsleer van Calvyn en Barth vir 'n oomblik in beskouing geneem is, sal dit goed wees om ook te verneem wat die beoordeling hiervan is deur 'n ,.jonger" dogmatikus - Otto Weber.

Oor Calvyn val die beoordeling kortliks aldus :

33. Barth, a.w., bl. 29.

34. Barth, a.w., bl. $30 / 31$. 
So weinig as wat die predestinasieleer van Calvyn uit die spekulasie gegroei het en soveel as wat hy vir teologiese konstruksie waarsku - net so weinig het hy hieraan ontkom. Dit sien Weber veral in die logiese en eensydige polêre gerigtheid van die verkiesing en verwerping teenoor mekaar.

„Zudem: wie sollte die Prädestinationslehre noch eine Christologische Mitte haben wenn Gottes Ja und Gottes nein als gegensätzliche Äquivalente auftraten ${ }^{35}$

Daardeur is die weg ook gebaan vir die gedagte dat die heilsgebeure net instrumentele en nie „begründende Bedeutung” het nie.

Aan die anderkant het Barth, volgens Weber, die hele probleem konsekwent onder die gesigspunt van die Christologie benader. Dat Jesus Christus self as die „Eersgeborene onder baie broeders" die voorwerp en middel van die goddelike verkiesing is, was reeds dikwels gesê. Die perspektief wat Barth open is nl.: as God self die een is wat uitverkies, is hierdie werk ook die werk van die Seun. Dit beteken: Jesus Christus is die uitverkiesende God en Hy is ook die uitverkore mens. ${ }^{38}$ Die uitverkiesende God is dus nie die „Deus nudus”, maar die „Deus incarnatus" - Hy is nie van huis uit neutraal om dan eers op grond van 'n wilshandeling hierdie of daardie mens tegemoet te tree in genade nie; in teendeel $\mathrm{Hy}$ is van huis uit/van meet af aan God vir die mense.

Net so is die mens van meet af aan in Christus geskep en in Hom uitverkies.

„Barth hat neu erkannt, das die Aussagen der Schrift darin zusammentreffen, dass der wählende Gott in Christus Gott ist für den menschen und der gewählte Mensch in eben diesen Christus Mensch ist für Gott." ${ }^{\prime 3}$

Hierdie indruk word versterk wanneer die verwerping in oënskou geneem word; soos Jesus Christus die Een Verkorene is, so is Hy ook diè Verworpene. In Jesus Christus het God ons verwerping verkies, die "Nee" as 't ware op Homself getrek en gedra. ${ }^{38}$ Sy ,nee", die verwerping, is dus eintlik vir Homself bedoel sodat die verwerping eintlik net as onmoontlike moontlikheid bestaan (lets „Ohnmächtiges”, „Sinnwidriges” teenoor die waarheidsgetuienis van die verkiesing.)

35. O. Weber, Grundlagen der Dogmatik (Neukirchen Moers 1962) II. bl. 474.

36. O. Weber, a.w., bl. 485, met verwysing na Barth, K.D. II, 2 bls.

37. Ed. Buess, aangehaal in $O$ Weber, a.w., bl. 485 .

38. O. Weber, a.w., bl. 485 (Barth K.D. II, 2). 
Die probleem word gekonsentreer op die vraag hoe Gods vryheid as vryheid vir die mense en vryheid in genade verstaan kan word. Hieroor lui Barth se tese : dit is slegs moontlik wanneer Christus nie verstaan word as net voorwerp en middel van die goddelike, vrye daad nie, maar juis self as ,der Wille Gottes in Aktion".

Daarmee is die uitverkiesingsleer uit die hoogte van 'n suiwer leer oor God teruggehou in die geskiedenis Gods met die mense en dit beteken: teruggehou in die verkondiging. ${ }^{39}$

\section{Betekenis van die Uitverkiesingsleer vir die Sending}

As daar nou n.a.v. wat gestel is oor die uitverkiesing enkele konsekwensies getrek moet word vir die sending, sal die sendingmotief eers kortliks in oënskou geneem moet word.

„Die een motief wat teenoor alle ander motiewe die voorrang moet geniet is naamlik die gehoorsaamheid aan die goddelike opdrag (Mat. 28:19, Hand. 1:8). Natuurlik moet mens hier altyd op die hoede wees om nie in 'n strak wettiese houding te verval nie, maar om gehoorsaam in die geloof te wees. Anders word die sending 'n sware plig wat al sugtende gedoen word.

Die Kerk bestaan nie maar toevallig nie, maar is met ' $n$ bepaalde opdrag in die wêreld gestuur. Daarom is die Kerk nooit sonder sy opdrag nie, ook nooit Kerk voor sy opdrag nie. Die Kerk het nie eers ontstaan en daarna sy opdrag gekry nie ontstaan en opdrag val saam. Sy opdrag is ook nie 'n las waaronder hy gebuk gaan nie, maar hy leef juis in die gehoorsame uitvoering van sy opdrag.

Sy opdrag ontvang die Kerk van sy Hoof Jesus Christus. En hierdie opdrag word deur Jesus Christus Self gedurig vernuwe deur die verligtende krag van Sy Woord en Gees.

En Christus wat self die oorsprong en inhoud van die geloof van Sy volgelinge is, is ook die inhoud van die opdrag aan die gemeente. Om Hom alleen gaan dit in die opdrag van die Kerk - om Hom bekend te maak, Sy getuies te wees.

As die Kerk sy opdrag werklik verstaan sal dit ook vir hom so gewigtig, so dringend en omvattend wees dat daar nie nog plek vir iets anders sal kan wees nie.

In hierdie opsig is ook ingesluit aan wie die Kerk hierdie goeie boodskap van Jesus Christus moet bring. Dit gaan naamlik

39. O. Weber, a.w., bl. 486 (Barth K.D. II. 2). 
om die mens, die mens as sodanig afgesien van sy aard of gesteldheid of wat ookal. Die mens is vir die Kerk belangrik nie op grond van sy eie waarde of waardigheid nie, maar omdat God waarde aan hom heg. Hierdie mens in sy vervreemdheid van die Evangelie, wat die kennis van hierdie Evangelie ontbeer en tog so nodig het, is die adressant van die Kerk in sy sendingshandeling. Die ontbering van die Evangelie is juis sy werklike nood en ellende." 40

Maar bowendien - dwarsdeur alle menslike motivering, metode en doelstelling - kan die sending slegs werk van die geloof wees. Die sending veronderstel die Kerk as die „plek" waar God Homself só openbaar, die menslike ken en doen só opneem, dat in Sy naam en diens en daarmee onder Sy seën en in Sy krag gehandel en gewerk moet word en in der daad gehandel en gewerk kan word.

Slegs met die oog op hierdie veronderstelling word die sending gewaag.

En as waagstuk is die sending 'n poging tot Kerklike gehoorsaamheid. Daarmee word aangedui dat die sending nie eiemagtig tot sending kan word nie, maar alleen in die geloof. Daarby is dit geen verdienste dat die sendingwerk van die geloof is nie, maar dis genade. Daarom moet mens volgens Barth versigtig wees met die Sendingmotief „d.h. sich selbst als eine wesensnotwendige Funktion der Kirche, als eine unentbehrliche Lebensäusserung der Christenheit zu rechtfertigen." 11

Die sending kan homself ten slotte nie regverdig nie, hy kan slegs hoop (en vurig bid) om akte van gehoorsaamheid te wees, sonder om ooit die hand daarop te kan lê as 'n hebbelikheid. God hou ook hier alles in Sy hand. Dit is 'n saak van goddelike verkiesing, wanneer die sending is wat hy moet wees : werk van die geloof, gehoorsame handeling van die Kerk.

Die wesenlike en eintlike wat in die sending moet geskied, geskied nie deur die menslike arbeid nie, maar deur die barmhartige welgevalle van Hom, wat hierdie arbeid vir Sy diens opeis en as werklike gehoorsaamheid aanneem, waar en wanneer Hy genadig wil wees. God is vrye liefde.

In die lig hiervan is dit duidelik dat dit vir die Kerk nie voor alles daarom kan gaan wie gered en wie verlore is, en wie uitverkies en wie verdoem is nie. Die Kerk kan net in nederigheid en ootmoed sy opdrag gehoorsaam in die gebed, in die hoop dat sy Hoof, wat ook in der waarheid eintlik Self die Sendeling

40. Prof. F. J. van Zyl, Klasaantek. 1967.

41. I. P. C. van t'Hof, Het Zendingsbegrip van K. Barth, (Hoenderloo, 1964) bl. 63 . 
is, hierdie diens en werksaamheid sal kan opneem in Sy diens om dit deur dic werking van Sy Heilige Gees waarlik tot sending te maak.

En hierby dien in gedagte gehou te word: predestineerdheid is ' $n$ waarheid van die eschaton (die laaste dag). Daarom kan ons nie sê mens kry verkorenes en verworpenes nie. Wel kan en moet ons glo - mens sal dit so kry. Ons gaan hierdie werklikheid tegemoet. Dit is ons menslike lewe dat ons op hierdie weg is. Maar ons mag nie hierdie toekomstige skeiding 'n teenswoordige gebeurlikheid maak nie. Maar ons sal in gehoorsaamheid ons situasie tussen hemelvaart en wederkoms moet aanvaar as die situasie waarin ons uit geloof lewe en nie uit aanskouing nie. ${ }^{42}$

En dit sal dan die sin en betekenis van die uitverkiesing in Christus vir die sending wees: Verkiesing beteken uitroeping uit hierdie "Gesammtheit aller" (almal onder die ongehoorsaamheid) en so beteken dit beweging, gebeurtenis. En dit is die stryd van die Kerk met die wêreld : dat hierdie beweging plaasvind, dat uit die „massa perditionis" altyd weer enkeles uitgeroep sal word om deur Christus regverdig, en as sodanig kragtens Gods ewige uitverkiesing, salig te word. ${ }^{43}$

Ten slotte moet daar ook teenoor die piëtistiese opvatting dat alle mense en volke wat van Christus nooit gehoor het nie die volgende gestel word:

In die Bybel is daar wel geen duidelike leer wat die ewige lot sal wees van hulle wat nooit van Christus gehoor het nie. Daar is egter genoeg aanduidings dat 'n leer van die algehele verlorenheid van die heidene nie sonder meer aanvaar kan word nie. Bowendien is so ' $n$ opvatting in stryd met die Pauliniese stelreël om nie te dink bo wat geskrywe is nie."4

Oor die probleem of die heidene verworpe is stel Barth:

Ons het vasgestel dat mens nie (in hierdie bedeling) kan praat van verkorenes en verworpenes nie. Daarom kan die heidene ook nie geteken word as verworpe nie. Ons weet slegs: hulle het die verkondiging nog nie gehoor nie. Ons het dit egter gehoor. Laat ons daarom nie daaroor besin of die heidene verworpe is nie - laat ons heengaan en aan hulle die Evangelie verkondig (gehoorsaamheid!).

„Der Kirche ist aufgetragen, Mission und nicht Spekulation zu treiben." ${ }^{45}$

42. Barth, a.w., bl. 48 .

43. Barth, a.w., bl. 46.

44. Prof. F. J. van Zyl, Klasaantek., 1967.

45. Barth, a.w., bl. 53. 